\title{
DETERMINAN PENYEBAB TERJADINYA KEJADIAN BALITA BAWAH GARIS MERAH DI WILAYAH KABUPATEN DHARMASRAYA
}

\author{
Siti Khotimah \\ Prodi D3 Kebidanan Universitas Dharmas Indonesia \\ Sitikhotimah900@gmail.com
}

\begin{abstract}
Toddlers under the red line are children who are underweight according to age compared to the standard which is known visually by looking at the plot on the card towards health (KMS) under the red line. Toddlers with BGM status in Dharmasraya Regency in 2017 amounted to 1.4\%. The purpose of this study was to determine the factors associated with the incidence of under-five under the red line in the working area of Koto Baru Public Health Center, Dharmasraya Regency. This research method is analytical survey. The population of this study were all toddlers aged 0-59 months in Jorong Pinang Gadang, as many as 74 toddlers. The sampling technique is the total population. The results of the study were obtained: almost all children under five did not experience BGM status, most of the respondents worked as housewives, most respondents had an income above the UMR in Dharmasraya Regency, almost all respondents had good knowledge of nutrition and based on the results of the chi-Square results show that there is a relationship between maternal employment status and the incidence of children under five $B G M$, there is a relationship between family income and the incidence of children under five BGM and there is no relationship between knowledge of nutrition and the incidence of children under five BGM. Suggestion For mothers who have toddlers to pay more attention to time management in giving food to toddlers related to the amount, type and frequency that is given.
\end{abstract}

Keywords: Lower metah line, employment status, family income, nutritional knowledge.

\section{ABSTRAK}

Balita bawah garis merah merupakan anak dengan berat badan kurang menurut umur di bandingkan dengan standar yang di ketahui secara visual dengan melihat plot dalam kartu menuju sehat (KMS) berada di bawah garis merah. Balita dengan status BGM di Kabupaten Dharmasraya pada tahun 2017 sejumlah 1,4\%. Tujuan penelitian ini adalah untuk mengetahui faktor-faktor yang berhubungan dengan kejadian balita bawah garis merah di wilayah kerja Puskesmas Koto Baru Kabupaten Dharmasraya. Metode penelitian ini adalah survey analitic. Populasi penelitian ini adalah seluruh balita yang berusia 0-59 bulan di Jorong Pinang Gadang yaitu sebanyak 74 balita. Teknik pengambilan sampel adalah total populasi. Hasil penelitian di dapatkan: hampir seluruh balita tidak mengalami status BGM, sebagian besar responden bekerja sebagai ibu rumah tangga, sebagian besar responden memiliki penghasilan diatas UMR Kabupaten Dharmasraya, hampir seluruh responden memiliki pengetahuan gizi yang baik dan berdasarkan hasil uji statistik chisquare di dapatkan hasil ada hubungan antara status pekerjaan ibu dengan kejadian balita BGM, ada hubungan antara pendapatan keluarga dengan kejadian balita BGM dan tidak ada hubungan antara pengetahuan tentang gizi dengan kejadian balita BGM. Saran Bagi ibu yang memiliki balita untuk lebih memperhatikan manajemen waktu dalam pemberian makanan pada balita terkait jumlah, jenis dan frekuensi yang di berikan.

Kata Kunci: Bawah garis metah, Status pekerjaan, Pendapatan keluarga, Pengetahuan gizi. 


\section{PENDAHULUAN}

Gizi merupakan salah satu indikator untuk menilai keberhasilan pembangunan kesehatan sebuah negara dalam membangun sumber daya manusia yang berkualitas. Permasalahan gizi yang masih menjadi masalah utama di dunia adalah malnutrisi. Malnutrisi dapat meningkatkan kerentanan anak terhadap penyakit dan mempengaruhi tumbuh kembang, gangguan gizi menggambarkan suatu keadaan akibat ketidak seimbangan antara zat gizi yang masuk ke dalam tubuh dengan kebutuhan tubuh akan zat gizi tersebut.

Ada beberapa hal yang sering merupakan penyebab gangguan gizi, baik secara langsung maupun tidak langsung. Sebagian penyabab langsung gangguan gizi, khususnya gangguan gizi pada pada bayi dana anak usia di bawah lima tahun (Balita) adalah tidak sesuainya jumlah zat gizi yang mereka peroleh dari makanan dengan kebutuhan tubuh mereka. Gizi yang buruk menyebabkan mudahnya terjadi infeksi karena daya tahan tubuh menurun. Sebaliknya penyakit infeksi yang sering menyebabkan meningkatnya kebutuhan akan zat gizi sedangkan nafsu makan biasanya menurun jika terjadi penyakit infeksi dapat mengakibatkan anak yang gizinya baik dan menderita gangguan gizi (Moehji, 2017).

Salah satu bentuk kekurangan gizi pada balita adalah bawah garis merah (BGM), yaitu letak titik berat badan anak yang berada bawah garis merah dalam grafik kartu menuju sehat (KMS). Kejadian BGM berhubungan dengan kurangnya pengetahuan dan keterampilan ibu tentang pengasuh anak, meliputi praktik pemberian makan pada anak, pemeliharaan kesehatan, dan kebersihan diri anak.

\section{Menurut World Health} Organization (WHO) mencatat sedikitnya $23 \%$ balita dunia mengalami berat badan yang rendah atau di bawah garis merah. Indonesia merupakan negara berkembang yang masih menghadapi masalah gizi. Prevalensi gizi anak balita dapat menggambarkan mengenai kondisi gizi masyarakat di suatu daerah. Data Riskesdas menunjukkan di Indonesia jumlah penderita gizi kurang tahun 2007 dan 2010 sebanyak 13,0\% sedangkan pada tahun 2013 meningkat menjadi $13,9 \%$. Banyak faktor yang mempengaruhi terjadinya kurang Gizi diantaranya adalah status ekonomi, rendahnya pengetahan ibu tentang pemberian gizi yang baik untuk anak, dan Berat Badan Lahir Rendah (kusriadi, 2015).

Menurut profil dinas kesehatan propisinsi sumatra barat pada tahun Pada Tahun 2017 Kasus Balita Gizi Buruk Ditemukan sebanyak 445 orang di Prov Sumbar, dan kasus balita di bawah garis merah (BGM) sebanyak 1.597 orang atau sebanyak 0.2 persen dari jumlah balita di timbang (Dinas Kesehatan Provinsi Sumater Barat, 2017).

Menurut profil Dinas Kesehatan Kabupaten Dharmasraya pada tahun 2014, berdasarakan laporan bidang kesda dinas kesehatan Kabupaten Dharmasraya, jumlah balita yang di timbang pada tahun 2014 berjumlah $14,814 \quad(73.5 \%)$ dari balita yang ada. Balita dengan BGM berjumlah 200 balita atau $1,4 \%$ dari balita yang di timbang (Dinas kesehatan Kab.Dharmasraya, 2014).

Berdasarkan data yang ada di Puskesmas Koto Baru, di dapatkan data berdasarkan laporan data persentase balita di bawah garis merah BGM) Puskesmas Koto Baru pada tahun 2017, terdapat $1.4 \%$ atau sekitar 62 orang balita dengan status BGM dan pada bulan Januari sampai dengan Agustus 2018, yaitu terdapat 2,6\% atau sekitar 64 orang balita dengan status dibawah garis merah.

Berdasarkan survei awal yang dilakukan peneliti di Jorong Pinang gadang Wilayah kerja Puskesmas Koto Baru Kabupaten Dharmasraya tanggal 07 Februari 2019 dari hasil 
Penimbangan berat badan balita menurut umur 10 balita didapatkan 1 orang balita (10\%) yang mengalami berat badan di bawah garis merah pada KMS.

Dampak kekurangan gizi sangat kompleks, anak dapat mengalami gangguan pada perkembangan mental, sosial, kognitif dan pertumbuhanya itu berupa ketidakmatangan fungsi organ, dimana manifestasinya dapat berupa kekebalan tubuh yang rendah yang menyebabkan kerentanan terhadap penyakit- penyakit seperti infeksi saluran pernafasan, dan diare. Usaha pemutusan rantai kekurangan gizi ini tentunya dibutuhkan pemetaan yang tepat untuk dapat mengetahui permasalahan utama yang menyebabkan terjadinya gizi kurang dan gizi buruk. Dampak jangka pendek dari kasus gizi kurang adalah anak menjadi apatis, mengalami gangguan bicara serta gangguan perkembangan yang lain, sedangkan dampak jangka panjang dari kasus gizi kurang adalah penurunan skor IQ, penurunan perkembangan kognitif, gangguan pemusatan perhatian, serta gangguan penurunan rasa percaya diri. Setiap daerah tentunya memiliki penyebab potensial gizi buruk dan gizi kurang yang berbeda-beda, sehingga penting untuk mengetahui permasalahan utamanya. Masalah gizi yang terjadi pada masa tertentu akan menimbulkan masalah pembangunan dimasa yang akan datang (Moehji, 2017).

Memberikan pelayanan gizi akan berakibat kerusakan yang sulit bahkan mungkin tidak dapat ditolong. Pemerintah dalam usahanya memerangi gizi buruk dan gizi kurang sudah cukup baik. Pemerintah sudah melakukan banyak program untuk menekan angka gizi buruk maupun gizi kurang, antara lain melalui revitalisasi Posyandu dalam meningkatkan cakupan penimbangan balita, penyuluhan dan pendampingan Pemberian Makanan Tambahan (PMT), peningkatan akses dan pelayanan kesehatan secara gratis, penanggulangan penyakit menular dan pemberdayaan masyarakat melalui keluarga sadar gizi (Kadarzi), tetapi angka gizi kurang dan gizi buruk masih tetap ada. Banyak faktor yang menjadi penyebab terjadinya angka gizi buruk dan gizi kurang, antara lain faktor kemiskinan, pendidikan dan pengetahuan orang tua, pola asuh orang tua, makanan pendamping, penyakit infeksi, keamanan negara, terbatasnya fasilitas kesehatan, tidak diberikan ASI Ekslusif, Berat Bayi Lahir Rendah (BBLR), nutrisi pada saat kehamilan (Adriani, 2014).

Berdasarkan latar belakang di atas maka penulis melakukan penelitian mengenai "Determinan penyebab terjadinya kejadian balita BGM di wilayah kerja Puskesmas Koto Baru Kabupaten Dharmasraya tahun 2019”.

\section{METODE}

Penelitian ini merupakan jenis penelitian survey analytic dengan rancangan cross sectional yaitu suatu penelitian untuk mempelajari dinamika kolerasi antara variabel dependen dengan variabel independen. Penelitian ini dilaksanakan pada Bulan Juni tahun 2019 di wilayah kerja Puskemas Koto Baru Kabupaten Dharmasraya. Sampel yang dijadikan responden adalah balita yang berusia 0-59 bulan sebanyak 74 orang balita yang diambil secara keseluruhan.

\section{HASIL}

Hasil penelitian yang telah dilakukan dapat dilihat pada tabel berikut ini:

Tabel 1 Distribusi Frekuensi Status Pekerjaan, Pengetahuan, Pendapatan ibu balia dan Status KMS di Jorong Pinang Gadang Wilayah Kerja Puskemas Koto Baru Kabupaten Dharmasraya tahun 2019

\begin{tabular}{lcc}
\hline \multicolumn{2}{c}{ Frekuensi } & Persentase (\%) \\
\hline Status Pekerjaan & & \\
\hline Tidak bekerja & 56 & 75,7 \\
\hline
\end{tabular}




\begin{tabular}{|c|c|c|}
\hline Bekerja & 18 & 24,3 \\
\hline Jumlah & 74 & 100 \\
\hline \multicolumn{3}{|c|}{ Pengetahuan Ibu } \\
\hline Rendah & \multicolumn{2}{|l|}{5} \\
\hline Tinggi & \multicolumn{2}{|l|}{69} \\
\hline Jumlah & \multicolumn{2}{|l|}{74} \\
\hline \multicolumn{3}{|c|}{ Pendepatan Keluarga } \\
\hline$<\operatorname{Rp} 2.119 .000$ & 24 & 32,4 \\
\hline$>\operatorname{Rp} 2.119 .000$ & 50 & 67,6 \\
\hline Jumlah & 74 & 100 \\
\hline \multicolumn{3}{|l|}{ Status KMS } \\
\hline BGM & 11 & 14,9 \\
\hline Tidak BGM & 63 & 85,1 \\
\hline Jumlah & 74 & 100 \\
\hline
\end{tabular}

Berdasarkan tabel 1 dari 74 responden di dapatkan bahwa sebagian besar responden tidak bekerja yaitu sebanyak 56 responden (75,7\%), Sebagian besar responden memiliki pendapatan $\geq$ Rp.2.119.000 berdasarkan UMR Kab. Dharmasraya yaitu sebanyak 50 responden $(67,6 \%)$, Hampir seluruhnya memiliki pengetahuan gizi yang tinggi yaitu sebanyak 69 responden $(78,4)$ dan Hampir seluruhnya balita yang ada di Jorong Pinang Gadang memiliki status KMS tidak BGM yaitu sebanyak 63 balita $(85,1 \%)$.

Tabel 2 Hubungan status pekerjaan ibu balita dengan kejadian BGM di Jorong Pinang Gadang Wilayah Kerja Puskesmas Koto Baru Kabupaten Dharmasraya tahun 2019

\begin{tabular}{|c|c|c|c|c|c|c|}
\hline \multirow{2}{*}{$\begin{array}{c}\text { Peker } \\
\text { jaan }\end{array}$} & \multicolumn{4}{|c|}{ Status KMS } & \multicolumn{2}{|c|}{ Total } \\
\cline { 2 - 6 } & \multicolumn{2}{|c|}{ BGM } & \multicolumn{2}{c|}{ Tidak BGM } & \multicolumn{2}{c|}{} \\
\cline { 2 - 6 } & $\mathrm{F}$ & $\%$ & $\mathrm{~F}$ & $\%$ & $\mathrm{~F}$ & $\%$ \\
\hline $\begin{array}{c}\text { Tidak } \\
\text { Bekerja }\end{array}$ & 3 & 5,4 & 53 & 94,6 & 56 & 100 \\
\hline Bekerja & 8 & 44,4 & 10 & 55,6 & 18 & 100 \\
\hline Total & 11 & 14,9 & 63 & 85,1 & 74 & 100 \\
\hline p-Value 0,000 & & & & & \\
\hline
\end{tabular}

Berdasarkan tabel 5 dari 74 responden yang tidak bekerja terdapat 3 responden $(5,4 \%)$ memiliki balita dengan status KMS BGM dan responden yang bekerja terdapat 8 responden ( $44,4 \%$ ) memiliki balita dengan status KMS BGM dan berdasarkan hasil uji statistik menggunakan uji chi square di peroleh nilai $\mathrm{p}$-value $=0,000<0.005$, artinya ada hubungan antara status pekerjaan ibu balita dengan kejadian balita BGM.

Tabel 3 Hubungan pendapatan keluarga dengan kejadian BGM di Jorong Pinang Gadang Wilayah Kerja Puskesmas Koto Baru Kabupaten Dharmasraya Tahun 2019

\begin{tabular}{|c|c|c|c|c|c|c|}
\hline \multirow{3}{*}{$\begin{array}{l}\text { Penda } \\
\text { patan }\end{array}$} & \multicolumn{4}{|c|}{ Status KMS } & \multirow{2}{*}{\multicolumn{2}{|c|}{ Total }} \\
\hline & \multicolumn{2}{|c|}{ BGM } & \multicolumn{2}{|c|}{ Tidak BGM } & & \\
\hline & $\mathrm{F}$ & $\%$ & $\mathrm{~F}$ & $\%$ & $\mathrm{~F}$ & $\%$ \\
\hline $\begin{array}{c}<\mathrm{Rp} . \\
2.119 .000\end{array}$ & 10 & 41,7 & 14 & 58,3 & 24 & 100 \\
\hline $\begin{array}{c}\geq \mathrm{Rp} . \\
2.119 .000\end{array}$ & 1 & 2.0 & 49 & 98,0 & 50 & 100 \\
\hline Total & 11 & 14,9 & 63 & 85,1 & 74 & 100 \\
\hline
\end{tabular}

Berdasarkan tabel 3 dari 74 responden yang memiliki pendapatan < Rp. 2.119.000 tedapat sebanyak 10 responden $(41,7 \%)$ memiliki balita dengan status KMS BGM dan responden yang memiliki pendapatan $\geq \mathrm{Rp}$. 2.119.000 terdapat 1 responden $(2.0 \%)$ memiliki balita dengan status KMS BGM dan berdasarkan hasil uji statistik menggunakan uji chi square di peroleh nilai p-value $0,000<0.005$, artinya ada hubungan antara pendapatan keluarga dengan kejadian balita BGM.

Tabel 4 Hubungan pengetahuan gizi dengan kejadian BGM di Jorong Pinang Gadang Wilayah Kerja Puskesmas Koto Baru Kabupaten Dharmasraya Tahun 2019

\begin{tabular}{|c|c|c|c|c|c|c|}
\hline \multirow{2}{*}{$\begin{array}{c}\text { Penge } \\
\text { tahuan }\end{array}$} & \multicolumn{4}{|c|}{ Status KMS } & \multicolumn{2}{|c|}{ Total } \\
\cline { 2 - 6 } & \multicolumn{2}{|c|}{ BGM } & \multicolumn{2}{c|}{ Tidak BGM } & \multicolumn{2}{c|}{} \\
\cline { 2 - 7 } & $\mathrm{F}$ & $\%$ & $\mathrm{~F}$ & $\%$ & $\mathrm{~F}$ & $\%$ \\
\hline Rendah & 0 & 0 & 5 & 100 & 5 & 100 \\
\hline Tinggi & 11 & 15,9 & 58 & 84,1 & 69 & 100 \\
\hline Total & 11 & 14,9 & 63 & 85,1 & 74 & 100 \\
\hline p-Value 0,751 &
\end{tabular}

Berdasarkan tabel 7 dapat dilihat dari 74 responden yang memiliki pengetahuan gizi rendah terdapat 0 responden $(0 \%)$ yang memiliki balita 
dengan status KMS BGM dan responden yang memiliki pengetahun gizi yang tinggi terdapat 11 responden $(15,9 \%)$ dengan status KMS BGM.

Hasil uji statistik menggunakan uji chi square di peroleh nilai p-value $=0,751>0.005$, artinya tidak ada hubungan antara pengetahuan gizi ibu balita dengan kejadian balita BGM.

\section{PEMBAHASAN}

\section{Status Pekerjaan Ibu Balita}

Salah satu dampak negatif yang timbul akibat dari ibu yang bekerja atau memilki kegiatan rutin di luar rumah adalah keterlantaran anak terutama anak balita. Masa depan anak dipengaruhi oleh pengasuhan dan keadaan gizi sejak usia bayi sampai anak berusia 5 tahun sebab usia tersebut merupakan usia penting bagi tumbuh kembang seseorang. Pada umur tersebut, anak belum dapat melayani kebutuhan sendiri dan bergantung pada ibu atau pengasuhnya

(Nurul, 2014)

\section{Pendapatan Keluarga}

Sosial ekonomi merupakan tingkat penghasilan keluarga yang mempengaruhi status gizi kurang pada balita merupakan salah satu faktor yang mempengaruhi gizi seimbang pada balita (Marmi, 2013).

\section{Pengetahuan gizi Ibu}

Pengetahuan merupakan hasil dari tahu, dan ini terjadi setelah orang melakukan penginderaan terhadap suatu objek tertentu. Penginderaan terjadi melalui pancaindra manusia, yakni indra penglihatan, pendengaran, penciuman, rasa dan raba, sebagian besar pengetahuan manusia diperoleh melalui mata dan telinga (Notoatmodjo, 2018).

\section{Balita Bawah Garis Merah (BGM)}

Bawah garis merah adalah anak dengan berat badan kurang menurut umur di bandingkan dengan standar, yang di ketahui secara visual dengan melihat plot dalam kartu menuju sehat (KMS) berada di bawah garis merah (Moehji, 2017).

Hubungan status pekerjaan ibu dengan kejadian BGM di Jorong Pinang Gadang wilayah kerja Puskesmas koto Baru Kab, Dharmasraya tahun 2019.

Penelitian ini sejalan dengan penelitian yang di lakukan oleh Nurul Budi Lestari dkk, pada tahun 2014 mengenai Faktor-Faktor Yang Berhubungan Dengan Kejadian Balita BGM di Desa Karangpasar Wilayah Kerja Puskesmas Tegowanu, yang menghasilkan p-value $=0,000<0,005$ artinya ada hubungn status pekerjaan responden (ibu balita) dengan kejadian BGM.

Bekerja bagi ibu-ibu akan mempunyai pengaruh terhadap kehidupan keluarga. Pekerjan adalah kegiatan yang harus di lakukan terutama untuk menunjang kehidupan keluarga. Pekerjaan bukanlah sumber kesenangan, tetapi lebih banyak merupakan cara mencari nafkah. Bekerja umumnya merupakan kegiatan yang menyita waktu (Nurul, 2014)

Dari penelitian yang telah di lakukan dan dari teori yang ada maka di simpulkan bahwa Ibu yang bekerja di luar rumah akan mempengaruhi pola asuh ibu terhadap anaknya, karena ibu yang memiliki kesibukan akan lebih banyak menghabiskan waktu untuk bekerja maka perhatian ibu dan pola asuh terhadap anak nya tentu saja berkurang, hal ini tentunya berhubungan dengan tumbuh kembang balita. Manajemen waktu yang kurang bagus mengakibtakan kurang nya perhatian ibu terhadap pemberian makan pada balita terkait jumlah, jenis dan frekuensi makanan yang diberikan.

\begin{tabular}{lrrrr} 
Hubungan & \multicolumn{2}{r}{ Pendapatan } & \multicolumn{2}{r}{ Keluarga } \\
dengan & kejadian & BGM & di & Jorong \\
Pinang & Gadang & Wilayah & Kerja
\end{tabular}


$\begin{array}{lll}\text { Puskesmas } & \text { Koto } & \text { Baru } \\ \text { Kab. Dharmasraya tahun 2019. } & \end{array}$

Penelitian ini sejalan dengan penelitian yang di lakukan oleh Nurul Budi Lestari dkk, pada tahun 2014 mengenai Faktor-Faktor Yang Berhubungan Dengan Kejadian Balita BGM di Desa Karangpasar Wilayah Kerja Puskesmas Tegowanu, yang menghasilkan p-value $=0,000<0,005$ artinya ada hubungn pendapatan keluarga dengan kejadian balita BGM.

Menurut Marimbi pada tahun 2013 ada beberapa faktor yang mempengaruhi gizi seimbang salah satunya adalah Ekonomi (terjangkau dengan kuangan keluarga), Rendahnya pendapatan merupakan rintangan yang menyebabkan orang tidak mampu membeli pangan dalam jumlah yang diperlukan. Sehingga tinggi rendahnya pendapatan sangat mempengaruhi daya beli keluarga terhadap bahan pangan yang akhirnya berpengaruh pada status gizi anak. Pada masa balita diperlukan lebih banyak zat gizi untuk pertumbuhan dan perkembangan.

Dari teori yang ada dan penelitian yang telah di lakukan maka peneliti berasumsi bahwa kurangnya kemampuan keluarga dalam memenuhi kebutuhan salah satunya adalah dalam pembelian bahan pangan yang tentu akan mempengaruhui status gizi pada anak, sedangkan pada masa pertumbuhan dan perkembangan sangat di perlukan makanan yang sehat dan bergizi.

\section{Hubungan pengetahuan gizi ibu dengan kejadian BGM di Jorong Pinang Gadang wilayah kerja Puskesmas koto Baru Kab, Dharmasraya tahun 2019.}

Penelitian ini tidak sejalan dengan penelitian yang di lakukan oleh Nurul Budi Lestari dkk, pada tahun 2014 mengenai Faktor-Faktor Yang Berhubungan Dengan Kejadian Balita BGM di Desa Karangpasar Wilayah Kerja Puskesmas Tegowanu, yang menghasilkan p-value $=0,043<0,005$ artinya ada hubungn pengetahuan ibu keluarga dengan kejadian BGM.

Pengetahuan merupakan hasil dari tahu, dan ini terjadi setelah orang melakukan penginderaan terhadap suatu objek tertentu. Penginderaan terjadi melalui panca indera manusia, yakni indera penglihatan, pendengaran, penciuman, rasa dan raba. Sebagian besar pengetahuan manusia diperoleh melalui mata dan telinga. Menurut teori peningkatan pengetahuan seseorang didapat dari tingkat pendidikan, informasi, budaya, dan pengalaman (Notoatmodjo, 2018).

Dari teori yang ada dan penelitian yang telah di lakukan maka peneliti berasumsi bahwa Ibu yang mempunyai pengetahuan baik maka semakin baik pula status gizi balitanya, sedangkan ibu yang pengetahuannya kurang akan berpengaruh terhadap pola makan dan pemilihan makanan yang akan berpengaruh terhadap status gizi. Dan salah satu sebab gangguan gizi adalah kurangnya pengetahuan gizi atau kemapuan untuk menerapkan informasi tentang gizi dalam kehidupan seharihari.

\section{SARAN}

Diharapkan penelitian ini dapat dijadikan sebagai informasi tambahan dan referensi serta bahan bacaan terkait dengan Balita Bawah Garis Merah terutama untuk ibu yang memiliki balita.

\section{DAFTAR PUSTAKA}

Adriani, M. \& Bambang, W. 2014. Gizi dan Kesehatan Balita. Jakarta: Kencana

Almushawwir, Muh Dhinul. 2016. Faktor- Faktor Yang Berhubungan Dengan Status Gizi Pada Anak Balita Di Wilayah Kerja Puskesmas Bontomarannu ".Skripsi. Makasar: Universitas Islam Negeri Alauddin Makassar 
Budi Lestari, Nurul dkk. 2013. FaktorFaktor Yang Berhubungan Dengan Kejadian Balita BGM di Desa Karangpasar Wilayah Kerja Puskesmas Tegowanu. Program Studi S1 Ilmu Gizi FIKKES Universitas Muhammadiyah Semarang.

Dinas Kesehatan Kota Dharmasraya. 2014. Profil Kesehatan Dinas Kesehatan Kota Dharmasraya Tahun 2014. Dharmasraya. Diakses pada tanggal 30 Oktober 2018.

Dinas Kesehatan Povinsi Sumatera Barat. 2017. Profil Kesehatan Dinas Kesehatann Provinsi Sumatera Barat. Diakses pada tanggal 21 januari 2019.

Dinas Tranmigrasi dan ketenegarkerjaan. UMR kab.Dharmasraya tahun 2018.

Kusriadi, 2015. Analisis Faktor Resiko Yang Mempengaruhi Kejadian Kurang Gizi Padaanak Balita Di Provinsi Nusa Tenggara Barat (NTB). Teseis. Bogor: Institusi Pertanian Bogor
Marimbi, Hanum. 2010. Tumbuh Kembang,Status Gizi, Dan Imunisasai Dasar Pada Balita. Yogyakarta : Nuha medika.

Marmi,. 2013. Gizi Dalam Kesehatan Reproduksi. Jakatra: Salemba Medika

Moehji, Sjahmien. 2017. Dasar-Dasar Ilmu Gizi. Jakarta: Pustaka kemang.

Muhammdah, Imam. 2012. Pemanfaatan SPSS Dalam Penelitian Bidang Kesehatan. Medan: Citapustaka Media Perintis

Notoatmodjo, S. 2018. Metode Penelitian Kesehatan. Jakarta: Rineka Cipta.

Putri Firman, R dkk. 2015. Faktor-Faktor Yang Berhubungan Dengan Status Gizi Anak Balita Di Wilayah Kerja Puskesmas Naggalo Padang. Universitas Andalas Padang. Volume 4 No 1

Sulistyawati, Ari. 2014. Deteksi Dini Tumbuh Kembang Anak. Jakarta: Salemba Medika. 